Алфра БК Универзитет, Београд

DOI 10.5937/kultura1653101J

УДК 725.945(497.1)"1960/1980"

72.071.1 Богдановић Б.

оригиналан научни рад

\title{
ETИЧКО ЧИТАНБЕ
} ВИЗУЕЛНИХ СИМБОЛА APXИTEKTE

\section{БОГПАНА БОГААНОВИПА}

Сажетак: Анализирајући интервјуе које је архитекта Богдан Богдановић дао за живота, а који су обједиґени у књизи Глиб и крв, могли бисмо да издвојимо две слике Београда које је гајио у себи. Митског града некадашњих старих иивилизаиија, Келта, подигнутом на мушком и женском симболу двеју река Дунава и Саве, град, који је наликовао на мешавину футуристичког модернизма и праисторијских некропола и насеља. Док је друга слика била обележена наглим променама у југословенском друштву од 1983.године када је предосећао и предвиђао да ће скоро сви градови на Балкану бити налик археолошким локалитетима на којима је затрпана у рушевинама једна култура и историја живота многих народа. Управо ћемо у овом раду преко анализе првог подигнутог споменика Јеврејским жртвама фашизма и палим бориима у Београду, покушати да откријемо једну универзалну симболику спомен обележја које је чувени архитекта изградио у пероду од 1960. до 1980.године. Тиме ћемо настојати, да се постави једно ново етичко читање скоро заборављеног језика симбола, визуелних знакова и уметности, којима су донекле оправдане природе човека-градитеља и човека-рушитеља у свима нама.

Кључне речи: Богдан Богдановић, спомен обележја, универзална симболика, етичко читање уметности, визуелни знак 


\section{Увод}

Свака честица човекова, свако његово занимање откривају га и показују га на исти начин као и сваког другог. ${ }^{1}$

Кроз историју многих народа упознајемо се са различитим митовима које су они стварали, што можемо да поредимо са сновима, јер ма колико да их има, они опет имају заједничко обележје и исти језик симбола. ${ }^{2}$ Тако је и сан о југословенству настао у социјализму, који је својим распадом од 1983. године прерастао у сурову реалност надметања зверске природе у свима нама. Универзални језик се заборавио, а етичко читање јавних споменика, нарочито Југословенске монументалне скулптуре посвећене револуцији, подигнуте у периоду од 1960. до 1980. године је прешло танку границу која је раздавајала национално од национализма.

Као један од најзначајних архитеката поменутог периода, је Богдан Богдановић. Професор Архитектонског факултета у Београду, некадашњи градоначелник Београда, упамћен као човек-градитељ, како је и сам говорио сакралне архитектуре комунизма ${ }^{3}-$ спомен обележја. То су: Спомен-гробље у Сремској Митровици, споменик Јеврејским жртвама у Београду, неропола у Прилепу, Слободиште у Крушевцу, Партизански споменик у Мостару, некрополе у Јасеновцу, Лесковцу, Белој Цркви, Партизанско гробље у Штипу, Адонисов олтар у Лабину, спомен обележја у Травнику, Власотинцу, Иванграду, Вуковару, Чачку, Клису.

У својим остварењима Богдан Богдановић је успевао да се уздигне изнад конвенционалних схватања и симбола. Усмеравајући своја идејна решења ка есенцијалним одредницама које произилазе управо из мотива, стварајући тако јединствена скулпторско-архитектонска решења. Да би све то постигао, морао је да проникне у саму суштину историјских збивања, да осети дух и енергију која из њих зраче. Непрестано се играо формама, трудећи се да упозна своје ђаке са тим покретачким идејама које извиру из прошлости и које чине историјски смисао мотива, стварајући тако јединствени уметнички израз, чија се етичка тумачења и до данас мењају и стављају у погрешну конотацију. ${ }^{4}$

1 Старобински, Ж. (2002) Монтеґ у кретању, Београд: Миљеш, стр . 77.

2 Фромм, Е. (1970) Заборављени језик, Загреб, Матица Хрватска, стр. 14.

3 Богдановић, Б. (2001) Глиб и крв, Београд, стр. 138.

4 Исто, стр. 32. Методологија игре које су за ииљ имале измииљағе хипотетичких градова и ичвилизачија и одигравање њихових хипотетичких (вероватних) судбина, припремане су месецима. За сат игре, требало је 3-4 дана припрема. Двадесет великих споменика револуцији. Да ли сте намерно учинили или се тако догодило да сте будуим генерацијама 


\section{АЛЕКСАНДАР ЈОКСИМОВИЋ}

\section{Етичко читање Југословенске монументалне скулптуре посвећеној револуцији}

Симболички језик је језик у којем су унутарња искуства, осећаји и мисли, изражени тако као да се одвијају у спољашњем свету. То је језик који има другачију логику од конвенционалног језика којим говоримо у току дана, логику у којој нису време и простор владајуће категорије већ интензитет и асоиирање. То је једини универзални језик с властитом граматиком и синтаксом, језик који човек мора разумети ако жели схватити значење митова, бајки, снова и

уметности. ${ }^{5}$

При конципирању јавног споменика, уметник се својом визијом неминовно конфронтира већ формираној масовној свести о историјском догађају или о појави која се споменички обележава. Како нешто што је нематеријално, претворити у материјално? Како избећи симбол националног идентитета у нечему што је заједничко за неке народе. Уколико погледамо само остварења Југословенске монументалне скулптуре посвећеној револуцији од 1960. до 1980. године ${ }^{6}$, уочићемо да су скоро сви уметници прибегавали симболима и метафорама добијеним из исконског искуства у обликовању спомен обележја многих претходних цивилизација. Стварајући на тај начин јединствену поетику споменика који пре свега делују на посматрача емоционално, доводећи га у стање контемплације и размишљања. Национално је у потпуности уступило место једној идеји духовне вредности. Постављамо питања колико су уметници и архитекте биле упознате са открићима археолошких локалитета у то време, Винче, Лепенског Вира? Да ли су проучавали ситуационе планове и трагали за магијским смислом најранијих протоурбаних и првих урбаних насеобина? Уколико се позабавимо анализом књижевног дела, архитекте Богдана Богдановића, написано давне 1966. године, ${ }^{7}$ добићемо одговоре на наша питања. Развијањем потреба код младих архитеката, да се истакне пребалканска култура у свом уметничком изражавању могли бисмо онда преко археолошких налаза Дубовачко-жутобрдске културне групе препознати мотив једног универзалног језика који је био, распрострањен од ушћа Драве, до ушћа Олта и Лома у Дунав, од доњег Подунавља па све дуж

оставили шифроване поруке? Споменици ма како били различити, су само различита слика исте азбуке, различите речи од којих је састављена једна реченица.

5 Фром, Е. нав. дело, стр. 15.

6 Шакота, С. (1986) Југословенска монументална скулптура посвећена револуцији (1960-1980), Весник, бр. 31-32, Београд: Војни музеј, стр. 116.

7 Богдановић, Б. (1966) Урбанистичка митологија, Београд. 
Ђердапске клисуре. ${ }^{8}$ Према налазима праисторијске инкрустоване керамике, и антропоморфних фигурина, уочавамо да су народи ове пребалканске културне групе поштовали симболе соларног система, где су употребни предмети често добијали фунерални значај и тиме магијски, док су насеља постајала некрополе. Ни једно од тих архолошких насеља-некропола није имало фортификацијске бедеме, била су слободна у природи, окружена растињем, али на изабраном терену који је био обезбеђен од поплава и ерозије. ${ }^{9}$ Када се вратимо на анализу Југословенске монументалне скулптуре, уочавамо тежњу архитеката за складним уклапањем споменика у природну средину, нарочито када је у питању аутентични амбијент. Градитељи споменика односили су се са дужном пажњом према очувању документарне ситуације природне средине не желећи да наруше њену аутентику као сцену историјског догађања. Сагледавајући локације свих важних меморијала види се да је том проблему придаван велики значај. Пажљиво је студиран избор места, при чему су узимана у обзир оба битна чиниоца, простор са својим пејзажима и другим вредностима, и споменик са својим идејним значењем и обликом. Чиме су настајала једна нова насеља-некрополе страдалих током Другог светског рата.

Од најзначајнијих твораца спомен обележја и меморијалне скулптуре широм тадашње Југославије су: Бранко Коцмут (архитекта), Славко Тихец (вајар), Јакоб Шавиншек (вајар), Војин Бакић (вајар), Душан Џамоња (вајар), Ана Бешлић (вајар), Јованка Јефтановић (архитекта), Александар Зарин (ваjap), Бранко Бон (архитекта), Радета Станковић (вајар), Светислав Личина (архитекта), Првослав Јанковић (архитекта), Миодраг Живковић (вајар), Јован Солдатовић (вајар), Јанез Ленаси (вајар), Жива Барага (архитекта), Влада Величковић (архитекта), Нандор Глид (вајар), Јосип Сеисел (архитекта), Шиме Вулас (вајар), Ђорђе Злоковић (архитекта), Ладислав Фекете (архитекта), Јордан Грабул (вајар), Искра Грабул (вајар), Петар Мазев (сликар), Бранко Лазески (архитекта), Славко Тихец (вајар), Драго Тршар (вајар), Брацо Мушић (архитекта), Ото Лого (вајар), Петар Хаџи-Бошков (вајар), Бошко Кучански (вајар), Зденко Колацио (архитекта), Љубомир Денковић (вајар), Сава Суботин (архитекта), Светлана Кана Радевић (архитекта), Глигор Чемерски (скулптор и сликар), Растко Рађеновић, Алија Кучукалић (вајар). ${ }^{10} О н и$

8 Пековић, М. (2015) Антропоморфне фигурине бронзаног доба у српском подунављу, Београд: Војни музеј, стр. 167.

9 Пековић, М. (2013) Инкрустована керамика бронзаног доба у српском подунављу, Београд: Војни музеј, стр. 118.

10 Шакота, С. нав. дело, стр. 121-135. 
су нам оставили велики број уметничких дела, визуелних знакова, који су се тешко етички ишчитавали и у њихово време, али који су временом схватани, прихватани и слављени. Нестајањем и сменом генерација у последњих 25 година, усмена предања о местима сећања су почела да бледе, скоро да нестају. Услед хаоса који је завладао деведесетих година 20. века, није било битно зарад којих идеја и због чега су многи животи нестали у Другом светском рату. То су постала места где су се пребројавале националности, и где је превагу да се једно спомен обележје сачува, одлучивало, кога је било више. Изворно, сва дела Југословенске монументалне скулптуре посвећена револуцији, су представљала савремену транспозицију традиционалног сепулкралног стваралаштва, у виду стећака, крајпуташа, сеоске архитектуре, стилизованих косовских божура, расцветалих цветова, птица, људи у кретању. Пластични концепти тих скулптура ${ }^{11}$ својом упрошћеном органском формом, чистотом облика и геометризмом, били су сведени на најбитније елементе, знакове, визуелне симболе, који су код посматрача наглашавали унутрашњу напетост, присећање великих губитака. Док су са друге стране дела вајарске архитектонике својим устремљењима ка простору и висинама, изражавала мотив полета, оптимизма, животне радости, исконске надчовечанске снаге.

Долазимо до закључка како су сви поменути уметници били усмерени на конкретне историјске појаве, да би се временом, тај круг ширио и обухватио и теме универзалног значења. На основу тога све меморијале (места сећања) и монументалне скулптуре не треба никако другачије ишчитавати, него као везу са прошлошћу, са блиским људима којих више нема, или пак догађајима који су пресудно утицали на данашњи живот. Споменици као да представљају неку врсту уговора о не нападању и мирној коегзистенцији склопљеног између два велика света, под условима које је са пуно такта и уважавања свету мртвих наметнуо свет живих. ${ }^{12}$ На нама је да овај уговор не прекршимо.

\section{Етичко читане визуелних симбола монументалне скулпуре Богдана Богдановића}

Бројна спомен обележја које је подигао архитекта Богдан Богдановић носе атрибуте аутентичних уметничких

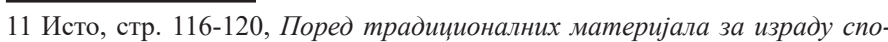
меника, као што су камен и бронза, широко се употребљавају и нови материјали, бетон, алуминијум, челик.

12 Чоловић, И. (1976) Кьижевност на гробљу - Збирка нових епитафа, Београд, Народна књига, стр. 85. 
дела, која се издвајају према специфичним композицијама и формама. Да ли се радило о споменику, спомен-обележју, маузолеју, некрополи, или кенотафу, атхитекта је неприкосновено поштовао онај низ узајамно повезаних просторно-пластичних елемената, интегративно сагледавајући позицију споменика у јединственом амбијенту, што је била и остала препознатљива одлика његовог рада. Из свега тога визуелни симболи споменика настали су под утицајем снажне уметникове личности, као пример како треба мислено градити. Симболизација над историјском фактографијом је сама по себи легитиман процес, али уколико смо у том процесу митологизације једног историјског догађаја правични, објективни и хумани, онда тај тренутак постаје опште људски - универзални симбол, који се претаче у традициjу. ${ }^{13}$ Етичко читање визуелних симбола монументалне скулптуре Богдана Богдановића, започињемо са његовим првим и јединим делом у Београду, спомеником Јеврејским жртвама фашизма и палим борцима из 1952, надовезујући се на спомен обележја у Прилепу, Крушевцу, Мостару, Травнику, Косовској Митровици, Чачку, Врњачкој Бањи. Број подигнутих споменика је много већи, али ћемо се у овом раду бавити споменицима подигнутим управо у периоду од 1960. до 1980. године.

Споменик Јеврејским жртвама фашизма и палим борцима, је прво дело, настало по дипломирању 1952. године. Тада је млади архитекта овај позив схватио врло озбиљно, изучавајући Кабалу и историју јеврејског народа на овим просторима. Према нацртима, споменик је формом у антиперспективи са природом терена сефардског гробља, чиме се добијао утисак сужавања парцеле. Јеврејска општина је добила помоћ од града Београда за изградњу споменика, у томе што је дозвољено да се са депонија грађевинског материјала од разрушених зграда услед бомбардовања, на обалама Дунава покупи све што је могло да се поново примени. Споменик је замишљен тако да свака породица може додати нешто своје од онога што је изгубила. Ишао сам тамо са мајсторима, препознавао сам фрагменте срушеног Београда, кућа којих can ce ceћao. ${ }^{14}$

Степениште фланкирано ниским бедемима, обрасло бршљеном, води нас ка споменику којег формирају два велика силазна зида. Прва асоцијација нам је као да се налазимо испред неког Кикладског храма, од кога је остало

13 Богдановић, Б. (2001) Глиб и крв, Београд, стр 14.

14 Лабудовић, И. и Богдан Богдановић, Престуn бр. 27, 01. 07. 2014., http:// www.makabijada.com/bogdan.htm 
сачувано прочеље, а унутар њега олтар са свећњаком. При пролазу кроз капију, ступамо у један микро свет, којим доминира спомен плоча жртвама у Другом светском рату. Са постаментом на коме се налази свећњак ствара се илузија крипте без таванице, али коју симболично чини крошња дрвета. Унутар сада тог простора свећњак има улогу граничника, новог прочеља, са једном другом сфером, у коју ступајући наилазимо на спомен плочу, и плочицу са именом аутора овог споменика. Симболика раздвојеног зида, прочеља, може се протумачити као Мојсијево чудо, раздвајањем Црвеног мора, и спасења. Као прелазак са овоземаљског у небески свет, као Мојсијеве плоче, са десет Божијих заповести, као подигнуте руке у молитви, као два племена јеврејског народа Коен и Леви. ${ }^{15}$ Управо се симболи ова два племена налазе на споменику, са једне стране, (лева страна споменика) у кованом гвожђу су стилизовано представљене подигнуте руке-симболи племена Коен, док је на десној страни у истом материјалу приказан врч и посуда-симбол племена Леви. Ако изоставимо поменуте визуелне симболе, и сагледамо споменик у његовом устремљењу ка простору и висини, главни мотив који препознајемо јесте величање исконске надчовечанске снаге.

\section{Прилеп (1961)}

На кружном платоу једне узвишице, постављен је низ пластичних тела исклесаних у белом камену који, на први поглед по форми, подсећају на стубове са капителима ${ }^{16}$, али све што их дуже посматрамо, они добијају облик џиновских антропоморфних фигурина. Овакав однос према надгробним споменицима подређен је потреби да се мртвима понуди нека врста загробног живота на месту сећања, где се антропоморфни споменици поистовећују са умрлима. ${ }^{17}$ Самостални су и сложени у мирну и свечану композицију, скоро немарну, трапаву ${ }^{18}$, што нам потврђују интервјуи Богдана Богдановића, у којима је износио мишљење да је праисторијска архитектура управо таква за њега. Капители су зооморфног

\footnotetext{
15 Рајнер М. Јеврејско гробље у Београду, 01. 07. 2014., http://www.makabijada.com/dopis/gradovi/grobgd/grobljebgd.htm

16 Шакота, С. нав. дело, стр. 124.

17 Чоловић, И. нав. дело, стр. 78.

18 Богдановић, Б. нав. дело, стр. 22-23. Тада сам помно проучавао археолошке материјале и ситуационе планове и трагао за магијским смислом најранијих протоурбаних и првих урбаних планиметријских фигура. Није било тешко уочити да се опсесивно издвајају две идеалне геометријске сенке којима су се прастари градитељи, градећи сасвим неидеално и трапаво своје насеобине ипак упорно дивили кругу као старија објава магијске жеље и затим дериваиије правог угла и по неки невешти квадpam.
} 
карактера и вуку корен из митологије, погребних култова или ритуала пребалканских народа указујући на везу између егејско-микенског и карпатско-подунавског подручја. Профили тих антропоморфних митолошких бића окренути су на разне стране просторног пејзажа, што наводи на помисао да се ради о симболичним чуварима посвећеног места. Визуелна симболика ових пластичних тела у Прилепу, код посматрача буди унутрашњу напетост и страхопоштовање, као да се налазе у светилиштима која су подигли Агамед ${ }^{19}$ и Битон $^{20}$, потом се буди осећање напуштености митског града мртвих и великих губитака.

\section{Крушеваи (1965)}

У меморијални комплекс се улази кроз Капију сунца као простор у којем започиње свет успомена и сећања, док је постављањем 12 скулпторских форми исклесаних у камену регулисано пејзажно решење терена. Ове форме по своjoj силуети подсећају на птице које узлећу са земље или на људске фигуре са подигнутим рукама. Стилизација форми је радикална, док је на њиховим површинама уклесана серија знакова у средњовековној орнаментици. Њихово визуелно симболично значење изражава поруку васкрсења, полета, оптимизма, животне радости која је јача од смрти. ${ }^{21}$

\section{Mocmap (1965)}

У овом меморијалу се осликава богата стилска полиморфија целог Балкана. ${ }^{22}$ Некропола је решена симбиозом скулптуралних, архитектонских и урбанистичких изражајних средстава. ${ }^{23}$ Шест степенастих тераса налик крововима обликују терен једне маркантне узвишице изнад самог града Мостара. Богате визуре испуњене су сплетом пластичних ознака метафоричног значења. Од камених плоча скинутих са старих мостарских кућа и облутака из Неретве саграђен је град сећања чије улице и тргови служе за сусрете са онима којих више нема и чије се дело не сме заборавити. Док је на самом врху брда подигнут круг са штитом, назван космос, на којем су приказани симболи сунца, месеца и звезда. Њихов универзални говор нагони на контемплацију о вечним темама живота и смрти. На овом споменику, као и у целом меморијалу, нема ничег акционог, агитаторског, победничког и

19 Срејовић, Д. и Цермановић-Кузмановић, А. (1989) Речник Грчке и Римске митологије, Београд, Српска књижевна задруга, стр. 2-3.

20 Исто, стр. 80-81.

21 Шакота, С. нав. дело, стр. 126.

22 Богдановић, Б. нав. дело, стр. 91.

23 Шакота, С. нав. дело, стр. 127. 
тријумфалистичког. ${ }^{24}$ Како ће ову грађевину тумачити после нас? Шта ће у юој доживети? Хоће ли деия, наше деце видети у овом споменику слику неког чудног, поносног и хуманог града, дигнутог као фатаморгана негде између неба и земље. И хоће ли у њему препознати свој град у једном давном, поносном, тешком времену када је најтеже било бити и остати човек. ${ }^{25}$

\section{Јасеноваи (1966)}

На комплексу Јасеновац, највећем концентрационом логору у Југославији, подигнут је споменик у виду цвета. За незамисливе патње и страдалништво изабрана је скулптурална метафора која изражава идеју да добро тријумфује вечно. Геометријском стилизацијом форме створен је кристално чист облик, богат алузивношћу и симболиком која не депримира, већ улива веру у живот. Док са једне стране бели камени цвет реално израста из тла попришта страдања, с друге, пак, стране се његова имагинарна представа огледа у водама Саве - такође, масовној гробници недужних жртава, што споменику даје посебну експресију у овом аутентичном пејзажу. ${ }^{26}$

\section{Косовска Митровица (1971)}

На Партизанском брду изнад града, где су сахрањени посмртни остаци рудара Трепче погинулих у НОР-у, подигнут је монументални споменик-кенотаф. Два импозантна стуба, са реминисценцијама на дорски стил, придржавају балдахин у виду преполовљеног цилиндра који подсећа на рударски вагонет. ${ }^{27}$ Због монументалних дорских стубова, стичемо утисак да се налазимо испред храма бога Јануса или двојне капије, посвећене овом старо-римско божанству, ${ }^{28}$ која је отварана приликом одласка у рат, а затварана када се закључи мир. Симболика кенотафа је нови почетак, као што је и божанство Јанус, бог сваког почетка, чувар света и космоса, а свака молитва и жртва без обзира на то, ком божанству је намењена, почиње његовим призивањем. Споменик

\footnotetext{
24 Богдановић, Б. нав. дело, стр. 121. Ако сам градио споменик у Мостару младим људима који су изгинули у партизанима и који су били муслимани, и хрушћани, и Срби, и Хрвати, ја сам морао да тражсим заједнички код , а заједнички код је био прекултни, он је ишао у просторе, у прабалканске форме. Ја сам се враћао на те прастаре форме, јер су оне могле да нас обједине.

25 Исто, стр. 180.

26 Шакота, С. нав. дело, стр. 127.

27 Исто, стр. 129.

28 Срејовић, Д. и Цермановић-Кузмановић, А. нав. дело, стр. 176.
} 
делује импресивно и достојанствено, а својом необичном силуетом снажно маркира пејзаж.

\section{Травник (1975)}

Некропола у Травнику има велике сличности са стилским решењем некрополе у Прилепу из 1961. године. Низ двочланих стела распоређених у простору, следи ону тежњу Богдана Богдановића о слободној, немарној архитектури. На обе стране сваке стеле, исклесана је у високом рељефу представа двоглавог змаја или змије, фунерарног знака, који вуче порекло из дубоке прошлости. ${ }^{29}$ Стилизовано обличје митолошке звери делује врло импресивно, симболишући тајновитост патњи и страдања, али у исто време нас подсећа на представе старо-римских генија ${ }^{30}$, који су представљани у виду змија, што би требало да истакне бесмртност душе. Снага пластичног израза ових стела и њихова диспозициja у простору, делују дубоком сугестивношћу која нагони на размишљање о основним принципима живота једног човека, народа, колектива или места.

\section{Чачак (1980)}

На маузолеју у Чачку, понавља се мотив Јанусовог храма или двојне капије, који имамо на кенотафу у Косовској Митровици из 1971. године. Маузолеј је остварен као грађевина једноставних и мирних облика, античких пропорција. Унутрашњи простор прати спољашњи облик грађевине који чине трапезоидни пилони наткривљени двосливним кровом. ${ }^{31}$ Читава грађевина, њен унутрашњи и спољашњи простор, обележени су фасцинантном скулптурском декорацијом исклесаном у јабланичком граниту. Низ косине пилона, како са спољне тако и унутрашње стране, од крова до базе, исклесани су профили грифона, укупно 620 обличја, од којих се ниједно не појављује два пута у истом облику. ${ }^{32}$ Грифон као митско биће, ${ }^{33}$ у коме је сједињена најјача птица (орао) и најјача животиња (лав), постао је симбол највеће анималне снаге. Тиме је изједначаван са божанском снагом. Оно што код нас буди зебњу јесте управо њихов приказ, где звер једна другу прождире. Ова богата зооморфна орнаментика набијена је симболичном енергијом страха од звери у нама самима, до осећаја тријумфа и ослобођења.

29 Шакота, С. нав. дело, стр. 131.

30 Срејовић, Д. и Цермановић-Кузмановић, А. нав. дело, стр. 94.

31 Шакота, С. нав. дело, стр. 134.

32 Богдановић, Б. нав. дело, стр. 106-109.

33 Срејовић, Д. и Цермановић-Кузмановић, А. нав. дело, стр. 99. 


\section{Врњачка Бања (1981)}

Просторни спомен-парк је подигнут у знак сећања на Попинску битку (1944. године) којег чине различита стереометријска тела, повезана међусобно по идејној основи цилиндричним отвором. ${ }^{34}$ Дубоко промишљен архитектонски склоп и међусобни просторни однос ових тела, распоређених у слободној природи, наговештава сакрални значај места. Богдан Богдановић је у овом спомен-парку објединио претходна два скулптурално-архитектонска и урбанистачка решења из Крушеваца и Мостара. Чисти облици и геометризам композиције делују уздржано и достојанствено, постепено откривајући слојевитост симболичког значења града мртвих. Док је цилиндрични отвор свих геометријских тела симбол почетка, космоса и бесконачности.

\section{Закључна разматрања}

Када сагледамо све споменике Југословенске монументалне скулптуре посвећене револуцији од 1960. до 1980. године, некако се враћамо на концепт комплексних активности које су спроводили у својој филозофији и раду Гауди, Хундертвасер. Надовезујући се на њих, младе архитекте једног новог режима Југословенства, својим радовима не желе да одузимају природи, која је имала превише губитака у Првом и Другом светском рату, већ да јој се прилагоде. Инспирисани фунералном уметношћу из праисторије, они су више у улози археолога-градитеља, где сваки померен камен са откривеног тумулуса враћају на своје место, у жељи да сачувају универзалну симболику праисторијског човека. Тим визуелним симболима су уједињавали све народе и народности, у слављењу пребалканских култова, у којима је соларни систем извор живота, пролазности и поновног рађања. Етичко ишчитавање ових визуелних симбола не може се остварити без познавања историје, која нас учи да не постоји независна традиција једног народа, већ сплет традиција многих других које једна другу богате. ${ }^{35}$

Архитекта Богдан Богдановић, је од свог првог споменика, подигнутом Јеврејским жртвама фашизма и палим борцима у Београду, постао свестан те релевантности у етичком ишчитавању уметничких форми монументалне скулптуре. Сви јавни споменици на првом месту обележавају мисли генерације која их подиже, насталој на мислима бројних генерација из прошлости. Уметник је у свему овоме медијум, који у једном визуелном симболу, обједињује све те мисли, сећања

34 Шакота, С. нав. дело, стр. 134.

35 Богдановић, Б. нав. дело, стр. 14. 
и праинспирације, смештене у садашњост. Тај континуитет се може остварити једино снагом његовог саопштења, унутрашњом логиком знакова и симбола. Колико се један јавни споменик или уметничко дело додирују са континуитетом људских сећања - антропологијом меморије, толико налазе своје место у времену ${ }^{36}$. На основу овога визуелни симболи југословенске монуметалне скулптуре посвећеној револуцији 1960 -1980 (расцветали божури, цветови, птице, људи у кретању, Јанусове двојне капије, пролази, кенотафи и градови изгубљених душа.... $)^{37}$ су код посматрача наглашавали унутрашњу напетост, присећање великих губитака, пролазности живота, али су исто својим формама изражавали мотиве поновног рађања - васкрсења, полета, оптимизма, животне радости, исконске надчовечанске снаге. У њиховом етичком ишчитавању, није постојало ничег националног. Нажалост данашња антропологија меморије народа на Балкану која се везује за ову монументалну скулптуру је у виду индиферентних подсетника, који се у зависности од времена стављају у погрешан контекст. На крају као утеха, нам остају речи Богдана Богдановића: У сваком случају, сигурно је да ти споменици неће генерацијама будућности говорити исто што и нама говоре, али важно је да не заћуте. ${ }^{38}$

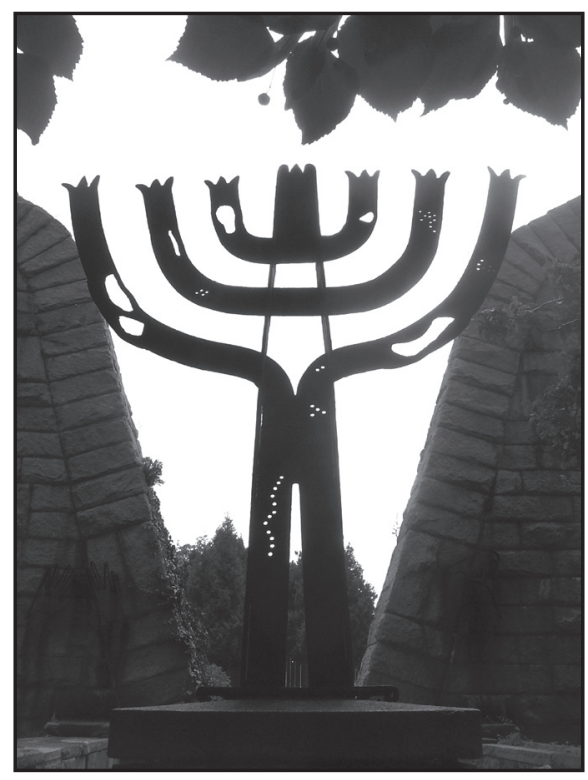

Јеврејско гробље, Београд, 2014, фото: Александар Јоксимовић

$\overline{36 \text { Исто, стр. 138-144. }}$

37 Шакота, С. нав. дело, стр. 116-120.

38 Богдановић, Б. нав. дело, стр. 32. 


\title{
ЛИТЕРАТУРА:
}

Богдановић, Б. (2001) Глиб и крв, Београд, преузето 04. 09. 2016. у 8:24, http://www.helsinki.org.rs/serbian/doc/Svedocanstva\%2009.pdf Пековић, М. (2015) Антропоморфне фигурине бронзаног доба у српском подунављу, Београд, Војни музеј, стр. 66-74.

Пековић М. (2013) Инкрустована керамика бронзаног доба у сриском подунављу, Београд, Војни музеј, стр. 118.

Рајнер, М. Јеврејско гробље у Београду, преузето 01. 07. 2014. у 12:25 http://www.makabijada.com/dopis/gradovi/grobgd/grobljebgd. $\mathrm{htm}$

Чоловић, И. (1976) Књижевност на гробљу - Збирка нових епитафа, Београд: Народна књига, стр. 78-85.

Срејовић, Д. и Цермановић-Кузмановић, А (1989) Речник Грчке и Римске митологије, Београд: Српска књижевна задруга, стр. 2-3, 80-81, 94, 99, 176.

Фром, Е. (1970) Заборављени језик, Загреб: Матица Хрватска, стр. 23-24.

Шакота, С. (1986) Југословенска монументална скулптура посвећена револуцији (1960-1980), Весник бр. 31-32, Београд: Војни музеј, стр. 116-135.

Aleksandar M. Joksimović

Alpha BK University, Belgrade

\section{AN ETHICAL READING OF VISUAL SYMBOLS OF ARCHITECT BOGDAN BOGDANOVIĆ}

\begin{abstract}
Analyzing various interviews given by the architect Bogdan Bogdanović, which were compiled in a book Glib i krv (Mud and Blood), we could discern two different images of Belgrade that he cherished in his mind. One was an image of a mythical city of old Celtic civilization, raised between the two rivers - the Danube and the Sava as male and the female symbols - which was a mixture of a futuristic modernism and prehistoric necropolis and settlements. The other image was imprinted with rough changes that the Yugoslav society underwent after 1983, which he had anticipated saying that almost all Balkan cities would end up like archeological sites, buried under ruins of a culture and history of many nations. This paper will also analyze the first monument raised in Belgrade in honour of the Jewish victims to fascism, and will try to discover a universal symbolic of the memorial monument this eminent architect built from 1960-1980. The intent is to offer an ethical reading of the almost forgotten language of symbols, visual signs and arts which partially justifies the nature of Man/Builder and Man/Destroyer found in all of us.
\end{abstract}

Key words: Bogdan Bogdanović, memorial monuments, universal symbolic, ethical reading of art, visual sign 